\title{
Keskusteleva kirja polveilee ja provosoi
}

Juha Suoranta (2003). Kasvatus mediakulttuurissa. Vastapaino.

Aikuiskasvatuksen professori Juha Suorannanteos Kasvatus mediakulttuurissa (Vastapaino 2003) on rohkean kriittinen kannanotto nykykulttuuriimme sekä median ja kasvatuksen tehtäviin. Kirjassa puhutaan paljon mediakasvatuksesta, mutta sitä voi lukea myös johdatuksena kriittiseen pedagogiikkaan ja sen kirjallisuuteen. Freiren, Althusserin ja Gramscin tapaiset klassiset vasta-ajattelijat lomit- tuvat Suorannan esseetyylisessä tekstissä tuoreeseen tutkimuskirjallisuuteen ja lehdistä poimittuihin esimerkkeihin. Kriittisen pedagogiikan suunnannäyttäjät Girouxja McLaren mainitaan kirjassa usein, ovathan nämä olleet nostamassa po- 
pulaarikulttuurin ja kasvatusinstituutioiden suhdetta keskustelunaiheeksi.

Suoranta kirjoittaa ihailtavan selväjärkisesti ja selkärankaisesti nykymaailman menosta. Kodeissa ja kouluissa tapahtuvan kasvatuksen hän näkee mediakulttuurin aikakaudellamme edelleen tarpeellisena ja suuria mahdollisuuksia sisäänsä kätkevänä. Lumovoimainen, kuluttamisperustaiseen viihtymiseen houkuttava media on otettava Suorannan mukaan kouluissa vakavasti, jos koulun halutaan jatkossa olevan merkityksellinen oppilaiden elämässä. Niin lapset, nuoret kuin vanhemmat ja opettajatkin ovat sisällä mediakulttuurissa, joka kasvattaa inmisiä omalla pedagogiikallaan, yleensä uusliberalistisen markkina-ajattelun myötäisesti.

Suorannan mielestä populaarikulttuuria ei tarvitse "juhlia" luokkahuoneissa, vaan sen tarjoamaa maailmankuvaa tulisi ruotia yhdessä lasten ja nuorten kanssa. Puhuessaan älyllisestä vastarinnasta opettajan tehtävänä Suoranta kuvaa koulun ja mediakulttuurin suhdetta näin (s. 134): "Mediakulttuurisessa tilanteessa koulun tehtävä ei voi olla pelkkä sopeuttaminen tai kasvattaminen vaan asettuminen vastavoimaksi niille kasvatusvaikutuksille, joita populaarikulttuuri ja mainonta tuottavat." Koulu voisi Suorannan mielestä tarjota vaihtoehdon valtamedian itsestään selvänä esittämälle kilpailun ja taloudellisen hyödyn maksimoinnin maailmalle. Parhaimmillaan koulu voisi totuttaa kaikki kansalaiset jo pienestä pitäen osallistumiseen, yhteistyöhön ja toisista välittämiseen Deweyn ihanteiden mukaisesti.

Suorannan kirjassa keskuste- lu mediakasvatuksesta näyttäytyy luontevana osana laajempaa koulu- ja kasvatuskeskustelua. Ihmiselämän medioitumista, mediavälitteisyyden lisääntymistä, suurempana ongelmana teoksessa nostetaan esille eriarvoisuuden lisääntyminen ja sitä tukeva mediasisältöjen ideologinen yhdenmukaisuus. Myös suomalaiseen koulutusjärjestelmään on Suorannan mukaan kasautunut eriarvoisuutta tukevia käytäntöjä, jotka estävät uudistavaa ajatteluaja oman elämän ottamista omiin käsiin. Tilalle Suoranta tarjoaa "kriittistäja elämänmyönteistä pedagogiikkaa", joka ammentaa paljossa Freiren toivon pedagogiikasta. Siinä ei sanota ainoastaan ei, vaan myös kuuluvalla äänellä kyllä, kun näkyviin ilmestyy aiempaa parempia käytäntöjäja eettisesti kestävämpiä polkuja kasvaa, oppia ja olla ihminen.

\section{"Keskustelu- kirjallisuutta"}

Suoranta kutsuu kirjansa tyyliä "keskustelukirjallisuudeksi", mikä onkin hyvä termi kuvaamaan sekä tekstin vapaataja liiasta akateemisesta kiertelystä riisuttua kieltä että sen kärkeviä kannanottoja ja harkittua provosoivuutta. Välillä ajatus soljuu vähän liiankin kerkeästi niin, että peräkkäisten kappaleiden yhteen liittymisen tapaa ei oikein tahdo oivaltaa.

Monipolvisuus kääntyy kuitenkin lopulta kirjan vahvuudeksi: aiheet vaihtelevat opettajankoulutuksesta median vaikuttavuuteen ja talousuutisoinnista työelämän kiihtyvään pakkotahtiin. Suositeltavaa rinnakkaislukemistoa kirjalle voisi olla Tomi Kiilakosken, Tuukka Tomperinja Marjo Vuorikos- kentoimittama teos Kenen kasvatus? (Vastapaino 2005), jossa kotimaiset kasvatustieteen tutkijat käsittelevät vielä monia muitakin ajankohtaisia aihepiirejä samaan kriittiseen henkeen.

Verrattuna Suorannan kolme vuotta aiemmin yhdessä Mauri Ylä-Kotolan kanssa kirjoittamaan teokseen Mediakasvatus simulaatiokulttuurissa (WSOY 2000) tämän kirjan teksti on paljon käytännönläheisempää ja selkeämpää, vaikka aiemman teoksen tieteenrajoja murtavat tulevaisuudenvisiot olivatkin sinänsä kiinnostavia.

Kasvatus mediakulttuurissa kirja on tiukasti kiinni todellisuudessa ja tässä ajassa. Mediakasvatuksella on lupauksensa, mutta Suorannalla ei ole epärealistisia kuvitelmia mediakasvatuksen kaikkivoipuudesta koulun tai suomalaisen "tietoyhteiskunnan" kehittämisen välineenä. Mediakulttuurin synnyttämistä uusista haasteista ja mahdollisuuksista huolimatta kasvatus perustuu Suorannan näkökannassa edelleen välittämiseen, huolehtimiseen ja jopa kutsumukseen.

ANTTO ILVONEN 